Jpn. J. Med. Sci. Biol., 47, 211 - 220, 1994.

Short Communication

\title{
TRANS-SUPPRESSION OF GENE EXPRESSION BY HEPATITIS C VIRAL CORE PROTEIN
}

\author{
Dong Wan KIM, Ryosuke SUZUKI1, Takashi HARADA1, \\ Izumu SAITO2 and Tatsuo MIYAMURA1
}

Department of Microbiology, College of Natural Science, Chang Won National University, Sarim-Dong, Chang-Won Shi, 641-773, Korea, 1Department of Virology II, National Institute of Health, Toyama 1-23-1, Shinjuku-ku, Tokyo 162, and 2 Laboratory of Molecular Genetics, Institute of Medical Science, the University of Tokyo, 4-6-1 Shirokanedai, Minato-ku, Tokyo 108

(Received October 4, 1993. Accepted September 30, 1994)

SUMMARY: We have demonstrated that the truncated hepatitis C (HCV) core protein with its C-terminal hydrophobic domains deleted is translocated to the nucleus of transfected cells (22). In this study, intact and truncated core proteins of HCV were transiently expressed in a human hepatoblastoma cell line, HepG2, and their effects on the expression of the chloramphenycol acethyl transferase (CAT) gene driven by viral and cellular promoters were examined. The intact core protein of $22 \mathrm{kDa}$ which is localized in the cytoplasm of the transfected cells suppressed the expression in all of the promoters tested. They were promoters of the SV40 early region, the $c$-fos oncogene, the retinoblastoma susceptibility gene, the $\beta$-interferon gene and the $\beta$-actin gene. In contrast, the truncated HCV core protein located in the nucleus did not show such a suppressive activity. The HCV core protein appears to function not only as a viral structural protein but as a regulator of gene expression and it might act as a suppressive factor for the cellular gene expression.

鈴木亮介·原田 卓·宮村達男 (国立予防衛生研究所ウイルス部)

斎藤 泉 (東京大学医科学研究所遺伝子解析施設 東京都港区白金台4-6-1) 
Hepatitis $\mathrm{C}$ virus (HCV) is the major causative agent of post transfusion and sporadic non-A, non-B hepatitis (1-3). It is clinically well known that HCV infection persists for a long time and eventually leads to hepatic cirrhosis and hepatocellular carcinoma (HCC) $(4,5)$. Although the mechanism is unknown, the HCV genome seems to persist in hepatic cells for decades and its gene products may play roles in the hepatocellular carcinogenesis. In Japan, deaths from HCC have been ominously increasing in number in the past two decades (6). At present, over $80 \%$ of HCC cases are considered to be related to HCV infection (5). The $\mathrm{HCV}$ genome is detectable in liver tissues of $\mathrm{HCC}(7,8)$. However, the integration of the viral genome is not found in HCV-infected HCC cells by Southern blotting analysis (7). The mechanism of the close relationship of HCV infection to the development of $\mathrm{HCC}$ is not known at all.

HCV contains a positive-stranded RNA genome of about 9.5 kilobases that encodes a large polyprotein precursor of about 3,000 amino acids (9-11). Analysis for its genomic structure revealed that HCV is distantly related to flaviviruses or pestiviruses (12-14). The structural proteins of HCV are considered to be encoded in the 5'-terminal region of the genome; nucleotide about 330 to $1,500(13,15)$. Like flaviviruses and pestiviruses, these proteins are cleaved from a large precursor polyprotein by cellular signalase (16). By analogy to these viruses, a nonglycosylated protein of $22 \mathrm{kDa}$ encoded by the $\mathrm{N}$-terminal portion of the open reading frame is considered to be the core protein of $\operatorname{HCV}(17,18)$.

HCV is an RNA virus and does not contain the reverse transcriptase. Its life cycle is consequently confined to the cytoplasm (19). However, the core protein of dengue virus, one of flaviviruses, is known to be partially transported into the nucleus (20). We previously found that the truncated HCV core protein was translocated to the nucleus when its cDNA was expressed in insect cells by a recombinant baculovirus or in monkey kidney cells by recombinant plasmids $(21,22)$. Such a truncated core protein of HCV with a smaller size is actually produced at later stage of transfection (Makimura et al., personal communication) or exclusively by a particular HCV isolate, HCV-1 (Makimura et al., personal communication). These lines of research prompted us to investigate to find whether the $\mathrm{HCV}$ core protein translocated to the nucleus influences the regulation of the host gene expression.

We first examined to find whether the translocation of the truncated HCV core protein to the nucleus takes place in human liver cells as in COS cells. The $\mathrm{HCV}$ core protein was expressed by using an exogeneous promoter and $\mathrm{HCV}$ cDNA isolated from a healthy HCV carrier (24). The full coding sequence of the 

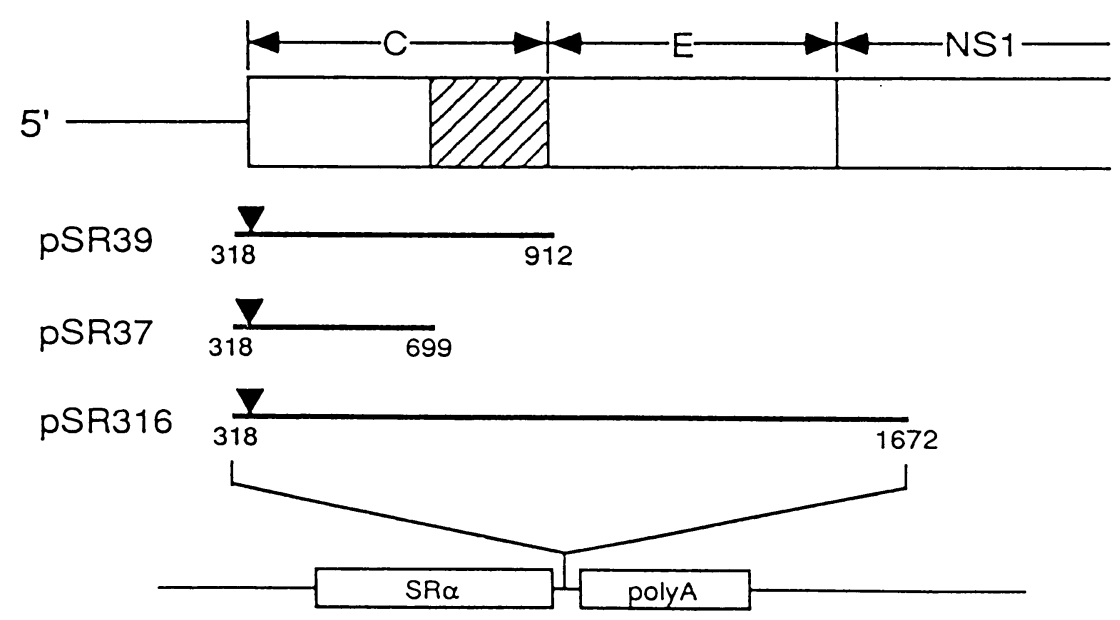

PCDLSR 2296

Fig. 1. Construction of the plasmids expressing intact or truncated core protein of HCV. Regions cloned under the $\mathrm{SR} \alpha$ promoter of pCDLSR $\alpha 296$ expression vector are shown. The nucleotide numbers of the cDNA of HCV are from Kato et al (9). C and E indicate coding regions of HCV structural proteins, core and envelope, respectively. The hatched box indicates the highly hydrophobic domain of the core protein (27). Triangles indicate the site of ATG.

core protein [nt318 to 912 , (9)] was inserted downstream of the $\mathrm{SR} \alpha$ promoter in the $\operatorname{pCDLSR} \alpha 296$ mammalian expression vector (25). This construction was designated as pSR39 in this study (Fig. 1). Similarly we constructed also two other recombinant plasmids with different $\mathrm{HCV}$ cDNA inserts. Plasmid pSR37 contains cDNA for the truncated core protein defective in two hydrophobic regions at its C-terminus [nt318 to 699]. Plasmid pSR316 contains the full coding region for core and envelope proteins under the control of $\mathrm{SR} \alpha$ promoter [nt318 to 1672]. HepG2 cells were transfected with each plasmid. The cells $\left(2 \times 10^{4}\right)$ cultured on 15-mm coverslips were transfected with $1.5 \mu \mathrm{g}$ of each plasmid DNA by the calcium-phosphate coprecipitation method (26). After $48 \mathrm{hr}$, the cells were fixed with acetone-methanol (1:1) at $-20 \mathrm{C}$ and examined for the expression of HCV core protein by indirect immunofluorescence assay (27). The serum of a patient with chronic hepatitis $\mathbf{C}$ containing antibody against the core protein was used as the first antibody. The second antibody was a rabbit anti-human immunoglobulin G. As shown in Fig. 2, the core protein expressed by the plasmids pSR39 and 

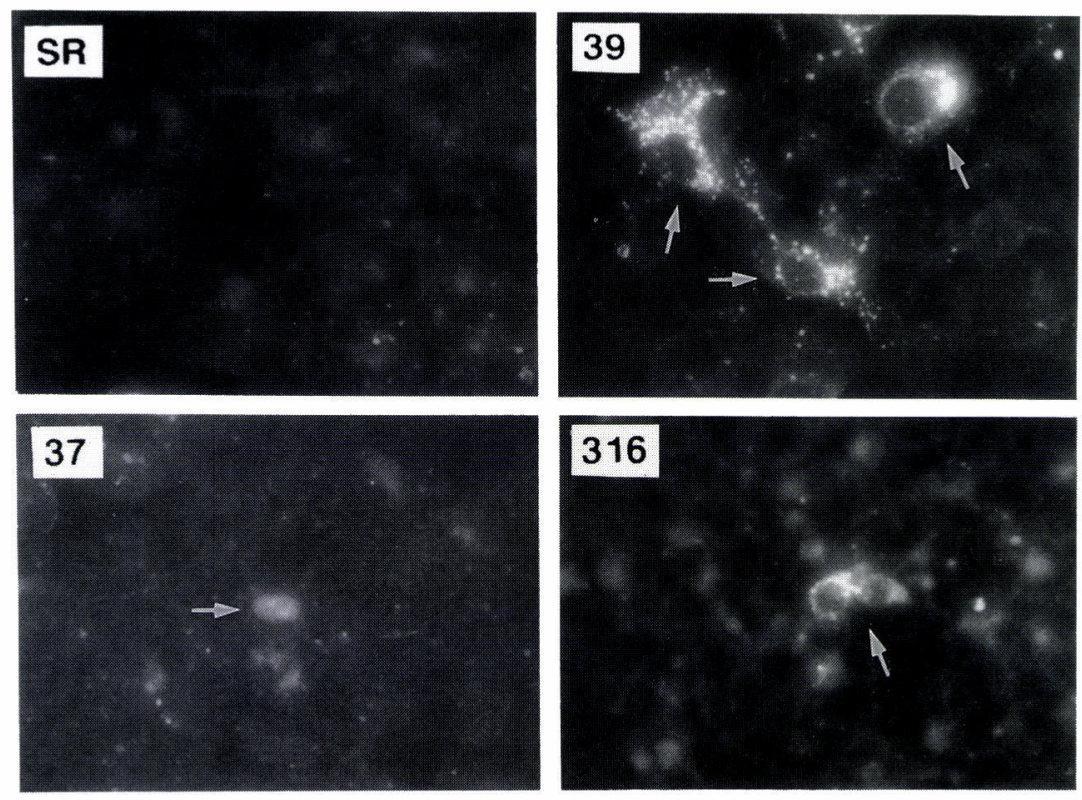

Fig. 2. Indirect immunofluorescence of HepG2 cells producing intact or truncated core protein. The cells cultured on $15-\mathrm{mm}$ coverlsips were transfected with $1.5 \mu \mathrm{g}$ of DNA of plasmid pSR39 (39), pSR37 (37), or pSR316 (316) and vector pCDLSR $\alpha 296$ (SR). Arrow-heads indicate the positive fluorescence in the cytoplasm (39 and 316) and in the nucleus (37).

pSR316 which contain the full coding region of the core protein was detected mainly in the cytoplasm. The truncated core protein expressed by the plasmid pSR37 lacking two C-terminal hydrophobic regions, however, was located exclusively in the nucleus. We could not detect the truncated HCV core protein in the cytoplasm. Translocation of the HCV core protein with the hydrophobic Cterminal domain deleted to the nucleus is consistent with the result previously obtained from the experiments using an other mammalian cell line, monkey COS cells, transfected with these recombinant plasmids $(21,22)$. By Western blotting analysis, as expected, the size of the intact core proteins expressed by pSR39 and pSR316 was $22 \mathrm{kDa}$ and the truncated core protein by pSR37 $17 \mathrm{kDa}$ (data not shown). Translocation of the truncated $\mathrm{HCV}$ core protein was recently confirmed by Shih et al. (28) in another liver cell line HuH-7 cells. 
We then examined the effect of the HCV core protein expression on a different gene. We first co-transfected HepG2 cells with each plasmid which expresses the intact or truncated core protein with CAT reporter plasmids containing the SV40 early region promoter. The CAT assay was performed according to the method of Gorman et al (29). Forty-eight hours after the transfection with CAT plasmid, the cells were rinsed twice with PBS and harvested by scraping with a rubber policeman. The cells suspended in $200 \mu \mathrm{l}$ of $0.25 \mathrm{M}$ Tris- $\mathrm{HCl}$ (pH 7.8) were disrupted by five cycles of freeze-thawing. The cell debris was removed by centrifugation and the lysate was examined for protein content by the method of Bradford (30). A sample of the cell lysate was incubated with $0.2 \mu \mathrm{Ci}$ of [14C]chloramphenicol (Amersham) and $1 \mathrm{mmol}$ of acetyl CoA (Sigma) in $0.25 \mathrm{M}$ Tris- $\mathrm{HCl}(\mathrm{pH} \mathrm{7.8)}$ at $37 \mathrm{C}$. The reaction products were extracted with ethylacetate and separated by ascending thin-layer chromatography with chloroform and methanol (95:5). The radioactive materials were located by autoradiography. As shown in Fig. 3 , the intact core protein expressed by plasmids pSR39 and pSR316 suppressed the expression of the chloramphenycol acethyl transferase (CAT) gene driven by the SV40 viral oncogene promoter. However, plasmid pSR37 did not show such a suppression. Such trans-suppression of intact core protein was observed in the CAT gene expression driven by cellular gene promoters as well. Functions of promoters of the chicken $c$-fos oncogene (31) and the human $\beta$ interferon gene (32) were also suppressed by pSR39 and pSR316, but not by pSR37. It was of interest that the CAT gene expression by the promoter of a tumor suppressor gene, retinoblastoma susceptibility gene (33), was suppressed similarly. Even the expression by the promoter of the housekeeping $\beta$-actin gene (34) was also suppressed by the intact core protein.

These results suggest that the intact HCV core protein has a general transsuppressive activity against cellular gene expression. This suppressive activity may be on the translation level, because the intact core protein is located only in the cytoplasm. Replication of hepatitis B virus (HBV) was suppressed in another human liver cell line, HuH-7 cells, when it was contransfected with HCV cDNA. In this case, however, the suppression was considered to be at a transcription level (28). Whether this suppression reported here occurs on the transcription or translation level has to be examined. Analysis of the transcripts may be necessary.

The core protein in the virion binds to viral RNA in the cytoplasm to form a nucleocapsid. If the HCV core protein binds not only to viral but to various cellular mRNAs under certain circumstances, it may down-regulate the translation of 


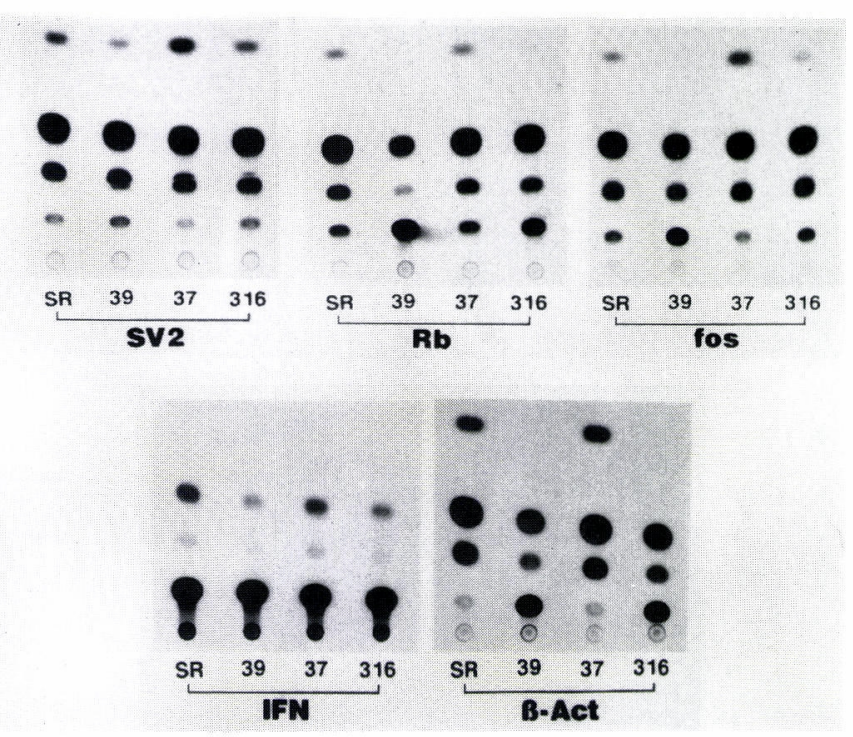

Fig. 3. Effects of intact or truncated HCV core protein on the expression by various promoters. HepG2 cells cultured on 6-cm plates were cotransfected with $6 \mu \mathrm{g}$ of indicated core protein expressing plasmid together with $2 \mu \mathrm{g}$ of CAT reporter plasmid by the calcium-phosphate coprecipitaion method. After $48 \mathrm{hr}$, the cells were harvested and lysed by five cycles of freeze-thawing. The CAT activities were estimated by use of [14C]labeled chloramphenicol. The promoters were SV40 early region promoter (SV2), retinoblastoma susceptibility gene promoter ( $\mathrm{Rb}$ ), chicken $c$-fos oncogene promoter (fos), human $\beta$-interferon gene promoter (IFN) and chicken $\beta$-actin gene promoter $(\beta$-Act).

such mRNAs resulting in general suppression of cellular gene expression. Satolini et al. (35) recently demonstrated the RNA-binding activity of the HCV core protein by showing that the $\mathrm{N}$-terminal portion of the $\mathrm{HCV}$ core protein binds to HCV- as well as HBV-RNA. The trans-suppressive activity of the HCV core protein does not directly explain the development of HCC. However, it is of interest to note that the $\mathrm{HCV}$ core protein possibly down-regulates the expression of cellular tumor suppresser genes. This may be one of the multiple triggers of cascades resulting in hepatocarcinogenesis. Another possible biologically significant futures of this finding may be that the slow, persistent infection with $\mathrm{HCV}$ is relat- 
ed to the down-regulation of the general gene expression of HCV-infected cells and autologous viral replication.

\section{ACKNOWLEDGEMENTS}

We thank Drs. Y. Matsuura, T. Suzuki and J. Chiba for their discussions, Ms. Y. Hirama for her technical assistance and Ms. T. Mizoguchi for her preparation of the manuscript. This study was supported in part by a Grant-in-Aid from the Ministry of Health and Welfare of Japan and a Research Grant of the Princes Takamatsu Cancer Research Fund. D-W. K. is a foreign research fellow of the Japan Health Science Foundation.

\section{REFERENCES}

1. Alter, H. J., Purcell, R. H., Shih, J. W., Melpolder, J. C., Houghton, M., Choo, Q-.L. and Kuo, G. (1989): Detection of antibody to hepatitis C virus in prospectively followed transfusion recipients with acute and chronic non-A, non-B hepatitis. N. Engl. J. Med., 321, 1494-1500.

2. Kuo, G., Choo, Q.-L., Alter, H. J., Gitnick, G. L., Redeker, A. G., Purcell, R. H., Miyamura, T., Dienstag, J. L., Alter, M. J., Stevens, C. E., Tegmeiier, G. E., Bonino, F., Colombon, M., Lee, W.-S., Kuo, C., Berger, K., Shuster, F. R., Overby, L. R., Bradley, D. W. and Houghton, M. (1989): An assay for circulating antibodies to a major etiologic virus of human non-A, non-B hepatitis. Science, 244, 362-364.

3. Miyamura, T., Saito, I., Katayama, T., Kikuchi, S., Tateda, A., Houghton, M., Choo, Q.-L. and Kuo, G. (1990): Detection of antibody against antigen expressed by molecularly cloned hepatitis $\mathrm{C}$ virus cDNA: application to diagnosis and blood screening for posttransfusion hepatitis. Proc. Natl. Acad. Sci. USA, 87, 983-987.

4. Saito, I., Miyamura, T., Ohbayashi, A., Harada, H., Katayama, T., Kikuchi, S., Watanabe, Y., Koi, S., Onji, M., Ohta, Y., Choo, Q.-L., Houghton, M. and Kuo, G. (1990): Hepatitis $C$ virus infection is associated with the development of hepatocellular carcinoma. Proc. Natl. Acad. Sci. USA, 87, 65476549.

5. Watanabe, Y., Harada, S., Saito, I. and Miyamura, T. (1991): Prevalence of antibody against the core protein of hepatitis $\mathrm{C}$ virus in patients with hepatocellualr cartinoma. Int. J. Cancer, 48, 340-343. 
6. Bureau of Vital Statistics, Ministry of Health and Welfare, Japan (1989): The number of cancer deaths and age-specific cancer mortality rates by site in Japan in 1987. Jpn. J. Clin. Oncol., 19, 181-193.

7. Yoneyama, T., Takeuchi, K., Watanabe, Y., Harada, H., Ohbayashi, A., Tanaka, Y., Yuasa, T., Saito, I. and Miyamura, T. (1990): Detection of hepatitis $\mathrm{C}$ virus $\mathrm{cDNA}$ sequence by the polymerase chain reaction in hepatocellular carcinoma tissues. Jpn. J. Med. Sci. Biol., 43, 89-94.

8. Takeda, S., Shibata, M., Morishima, T., Harada, A., Nakao, A., Takagi, H. and Nagai, Y. (1992): Hepatitis $C$ virus infection in hepatocellular carcinoma. Cancer, 70, 2255-2259.

9. Kato, N., Hijikata, M., Ootsuyama, Y., Nakagawa, M., Ohkoshi, S., Sugimura, T. and Shimotohno, K. (1990): Molecular cloning of the human hepatitis C virus genome from Japanese patients with non-A, non-B hepatitis. Proc. Natl. Acad. Sci. USA, 87, 9524-9528.

10. Choo, Q.-L., Richman, K., Han, J., Berger, K., Lee, C., Dong, C., Gallegos, C., Coit, D., Medina-Selby, A., Barr, P. J., Weiner, A. J., Bradley, D. W., Kuo, G. and Houghton, M. (1991): Genetic organization and diversity of the hepatitis C virus. Proc. Natl. Acad. Sci. USA, 88, 2451-2455.

11. Takamizawa, A., Mori, C., Fuke, I., Manabe, S., Murakami, S., Fujita, J., Onishi, E., Andoh, T., Yoshida, I. and Okayama, H. (1991): Structure and organization of the hepatitis $\mathrm{C}$ virus genome isolated from human carriers. J. Virol., 65, 1105-1113.

12. Miller, R. H. and Purcell, R. H. (1990): Hepatitis C virus shares amino acid sequence similarity with pestiviruses and flaviviruses as well as members of two plant virus supergroups. Proc. Natl. Acad. Sci. USA, 87, 2057-2061.

13. Takeuchi, K., Kubo, Y., Boonmar, S., Watanabe, Y., Katayama, T., Choo, QL., Kuo, G., Houghton, M., Saito, I. and Miyamura, T. (1990): Nucleotide sequence of core and envelope genes of the hepatitis $\mathrm{C}$ virus genome derived directly from human healthy carriers. Nucleic Acids Res., 18, 4626.

14. Han, J. H., Shyamala, K. H., Richman, K. H., Brauer, M. J., Irvine, B., Urdea, M. S., Tekamp-Olson, P., Kuo, G., Choo, Q-L. and Houghton, M. (1991): Characterization of the terminal regions of hepatitis $C$ viral RNA: identification of conserved sequences in the 5' untranslated region and poly(A) tails at the 3' end. Proc. Natl. Acad. Sci. USA, 88, 1711-1715.

15. Okamoto, H., Okada, S., Sugiyama, Y., Yotsumoto, S., Tanaka, T., Yoshizawa, H., Tsuda, F., Miyakawa, Y. and Mayumi, M. (1990): The 5'-terminal sequence of the hepatitis $C$ virus genome. Jpn. J. Exp. Med., 60, 167-177.

16. Houghton, M., Weiner, A., Han, J., Kuo, G. and Choo, Q.-L. (1991): Molecular biology of the hepatitis $C$ viruses: implications for diagnosis, development and control of viral disease. Hepatology, 14, 381-388.

17. Harada, S., Takeuchi, K., Suzuki, T., Katayama, T., Watanabe, Y., Takebe, Y., Saito, I and Miyamura, T. (1991): Expression of processed core protein of hepatitis $\mathrm{C}$ virus in mammalian cells. J. Virol., 65, 3015-3021. 
18. Chiba, J., Ohba, H., Matsuura, Y., Watanabe, Y., Katayama, T., Kikuchi, S., Saito, I. and Miyamura, T. (1991): Serodiagnosis of hepatitis C virus (HCV) infection with an HCV core protein molecularly expressed by a recombinant baculovirus. Proc. Natl. Acad. Sci. USA, 88, 4641-4645.

19. Choo, Q.-L., Kuo, G., Weiner, A. J., Overby, L. R., Bradley, D. W. and Houghton, M. (1989): Isolation of a cDNA clone derived from a blood-borne non-A, non-B viral hepatitis genome. Science, 244, 359-362.

20. Tadano, M., Makino, Y., Fukunaga, T., Okuno, Y. and Fukai, K. (1989): Detection of dengue 4 virus core protein in the nucleus. I. A monoclonal antibody to dengu 4 virus reacts with the antigen in the nucleus and cytoplasm. J. Gen. Virol., 70, 1409-1415.

21. Suzuki, R., Ando, A., Harada, S., Matsuura, Y., Saito, I. and Miyamura, T. (1991): Analysis of the HCV genome coding for core protein. The Third International Symposium on Viral Hepatitis and Hepatocellular Carcinoma. p.110. Taipei, Taiwan.

22. Suzuki, R., Matsuura, Y., Suzuki, T., Ando, A., Chiba, J., Harada, S., Saito, I. and Miyamura, T. (1994): Nuclear localization of the truncated hepatitis $\mathrm{C}$ virus core protein with its hydrophobic C-terminus deleted. J. Gen. Virol., in press.

23. Lo, S.-H., Selby, M., Tong, M. and Ou, J.-H. (1994): Comparative studies of the core gene products of two different hepatitis $\mathrm{C}$ virus isolates: Two alternative forms determined by a single amino acid substitution. Virology, 199, 124-131.

24. Takeuchi, K., Kubo, Y., Boonmar, S., Watanabe, Y., Katayama, T., Choo, QL., Kuo, G., Houghton, M., Saito, I. and Miyamura, T. (1990): The putative nucleocapsid and envelope protein genes of hepatitis $\mathrm{C}$ virus determined by comparison of the nucleotide sequences of two isolates derived from an experimentally infected chimpanzee and healthy human carriers. J. Gen. Virol., 71, 3027-3033.

25. Takebe, Y., Seiki, M., Fujisawa, J., Hoy, P., Yokota, K., Arai, K., Yoshida, M. and Arai, N. (1988): SR $\alpha$ promoter: an efficient and versatile mammalian cDNA expression system composed of the simian virus 40 early promoter and the R-U5 segment of human T-cell leukemia virus type 1 long terminal repeat. Mol. Cell. Biol., 8, 466-472.

26. Graham, F. L. and Van der. Eb, A. J. (1973): A new technique for the assay of infectivity of human adenovirus 5 DNA. Virology, 52, 456-467.

27. Kim, D.-W., Uetsuki, T., Kaziro, Y., Yamaguchi, N. and Sugano, S. (1990): Use of the human elongation factor $1 \alpha$ promoter as a versatile and efficient expression system. Gene, 91, 217-223.

28. Shih, C.-M., Lo, S. J., Miyamura, T., Chen, S.-Y. and Lee, Y.-H. W. (1993): Suppression of hepatitis $\mathrm{B}$ virus expression and replication by hepatitis $\mathrm{C}$ virus core protein in $\mathrm{HuH}-7$ cells. J. Virol., 67, 5823-5832. 
29. Gorman, C. M., Moffat, L. F. and Howard, B. H. (1982): Recombinant genomes which express chloramphenicol acetyltransferase in mammalian cells. Mol. Cell. Biol., 2, 1044-1051.

30. Bradford, M. M. (1976): A rapid and sensitive method for the quantitation of microgram quantities of protein utilizing the principle of protein-dye binding. Anal. Biochem., 72, 248-254.

31. Fujiwara, K., Ashida, K., Nishina, H., Miyajima, N., Nishizawa, M. and Kawai, S. (1987): The chicken $c$-fos gene: cloning and nucleotide sequence analysis. J. Virol., 61, 4012-4018.

32. Mosca, J. D. and Pitha, P. M. (1986): Transcriptional and posttranscriptional regulation of exogenus human beta interferon gene in simian cells defective in interferon synthesis. Mol. Cell. Biol., 6, 2279-2283.

33. Lee, W.-H., Bookstein, R., Hong, F., Young, L.-J., Shew, J.-Y. and Lee, E. Y.E. (1987): Human retinoblastoma susceptibility gene: cloning, identification, and sequence. Science, 235, 1394-1399.

34. Kanei-Ishii, C. and Ishii, S. (1989): Dual enhancer activities of the cyclicAMP responsive element with cell type and promoter specificity. Nucleic Acids Res., 17, 1521-1536.

35. Santolini, E., Migliaccio, G. and La Monica, N. (1994): Biosynthesis and biochemical properties of the hepatitis $\mathrm{C}$ virus core protein. J. Virol., 68, 36313641 . 